\title{
Determination of $\beta$-carbolines in Thai Picrasma javanica BI.; the source of potential antimalarial agents
}

\author{
Chalerm Saiin ${ }^{1 *}$, Juggreewut Junwised ${ }^{1}$, Nitra Nuengchamnong ${ }^{2}$ and Kornkanok Ingkaninan ${ }^{1}$ \\ ${ }^{1}$ Department of Pharmaceutical Chemistry and Pharmacognosy, Faculty of Pharmaceutical Sciences, Naresuan \\ University, Phitsanulok, Thailand. \\ ${ }^{2}$ Science Laboratory Centre, Faculty of Science, Naresuan University, Phitsanulok, Thailand.
}

Accepted 14 June, 2019

\begin{abstract}
The bark of Picrasma javanica Bl. (Family Simaroubaceae) has been widely used in the traditional medicines for the treatment of malaria in Myanmar, Indonesia and Thailand. In previous studies, thirteen $\beta$ carbolines were isolated from $P$. javanica growing in Indonesia and New Guinea. The present study aimed to identify the chemical components of Thai $P$. javanica by using thin layer chromatography (TLC) and high resolution mass spectrometry (MS). It demonstrated that there were at least six $\beta$-carbolines in stem bark of Thai $P$. javanica; composed of 1 -ethyl- $\beta$-carboline, 1 -ethyl-4-methoxy- $\beta$-carboline (crenatine), 4-methoxy-1vinyl- $\beta$-carboline (dehydrocrenatine), 5- or 6- or 8-dehydrocrenatine, 5- or 8-hydroxycrenatine, picrasidine G and picrasidine T. Three of them i.e. crenatine, dehydrocrenatine and 6-dehydrocrenatine had the antimalarial activities. Thus, Thai $P$. javanica shall be reserved as medicinal plant for malaria disease treatment.
\end{abstract}

Keywords: Thai Picrasma javanica Bl., Indole alkaloids, thin layer chromatography, mass spectrometry.

*Corresponding author. Email: Chalerms@nu.ac.th.

\section{INTRODUCTION}

Picrasma javanica $\mathrm{BI}$. is a medium size tree in the family Simaroubaceae. It's bark has been used in traditional medicines for the treatment of malaria in Myanmar, Indonesia and Thailand (Old Style Doctor Association, 1962). In 1942, during the II World War, 36 recipes of Thai Folk Medicine included $P$. javanica were used for treatment of either Plasmodium falciparum or $P$. vivax infected soldiers by Ketusinh (1948). Tangjitman et al. (2013) compared traditionally medicinal knowledge in 14 Karen villages in northern Thailand and determined culturally important medicinal plant in each Karen villages. $P$. javanica showed cultural important index $(\mathrm{Cl})$ of 0.96. Therefore, the chemical constituents and pharmacological activities of $P$. javanica should be studied thoroughly in order to justify the efficacy and safety of $P$. javanica as antimalarial drug among the
Karen in Thailand.

Saiin and Sirithunyalug (2017) reviewed the chemical structure of $\beta$-carbolines isolated from $P$. javanica. Most of fourteen indole alkaloids (Figure 1) were isolated from $P$. javanica growing in Indonesia and New Guinea. In Thailand, Pavanand et al. (1988) demonstrated that the chloroform extract of the bark possessed the high level of in vitro antimalarial activity against $P$. falciparum asexual stage. Further isolation and purification of the chloroform extract resulted in the identification of two pure alkaloids, 4-methoxy-1-vinyl- $\beta$-carboline and 6-hydroxy-4-methoxy1 -vinyl- $\beta$-carboline. The first compound was effective against $P$. falciparum isolates with mean $\mathrm{LC}_{50}$ of 2.4 $\mu \mathrm{g} / \mathrm{ml}$, while the second one showed mean $\mathrm{LC}_{50}$ of 3.2 $\mu \mathrm{g} / \mathrm{ml}$.

Moreover, several $\beta$-carbolines including naturally 
<smiles>CCc1nccc2c1[nH]c1ccccc12</smiles>

1<smiles>CCc1ncc(OC)c2c1[nH]c1ccccc12</smiles><smiles>CCc1ncc(OC)c2c1[nH]c1cccc(O)c12</smiles><smiles>CCc1ncc(OC)c2c1[nH]c1c(O)cccc12</smiles><smiles>CCC1N=CC(O)C2c3cccc(OC)c3NC12</smiles><smiles>CCc1ncc(OC)c2c1[nH]c1ccccc12</smiles>

6<smiles>COc1cnc(C(C)=O)c2[nH]c3ccccc3c12</smiles>
10<smiles>C=Cc1ncc(OC)c2c1[nH]c1cccc(O)c12</smiles>

7<smiles>O=C1CCC2N=CCC3=C2C12CCCC32</smiles>

11<smiles>CCc1ncc(OC)c2c1[nH]c1ccc(O)cc12</smiles>

8<smiles></smiles>

9

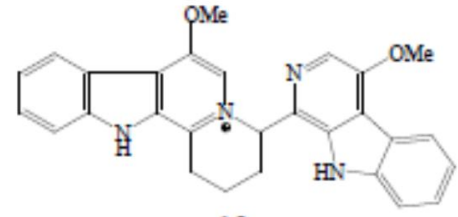

13

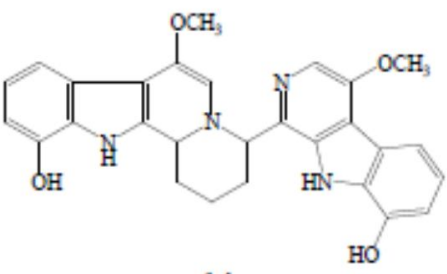

14<smiles>CCc1c(C)cc(C(=O)O)c2c1Cc1c([nH]c3ccccc13)C2=O</smiles>

12

Figure 1. Chemical structures of fourteen indole alkaloids isolated from $P$. javanica reported by Johns et al. (1970), Arbain and Sargent (1987), Ohmoto et al. (1987), Pavanand et al. (1988), Yoshikawa et al. (1993), Koike et al. (1994): (1); 1-Ethyl- $\beta$-carboline, (2); Crenatine [1Ethyl-4-methoxy- $\beta$-carboline], (3); 5 -Hydroxycrenatine [5-hydroxy-4-methoxy- $\beta$-carboline], (4); Picrasidine J [8-hydroxy-4-methoxy- $\beta$-carboline], (5); Crenatidine [4, 8-dimethoxy- $\beta$-carboline], (6); Dehydrocrenatine [4-methoxy-1-vinyl- $\beta$-carboline], (7); 5-Hydroxydehydrocrenatine [5Hydroxy-4-methoxy-1-vinyl- $\beta$-carboline], (8); 6-Hydroxy-4-methoxy-1-vinyl- $\beta$-carboline, (9); Picrasidine I [8-hydroxy-4-methoxy-1-vinyl- $\beta$-carboline], (10); 1-Acetyl-4-methoxy- $\beta$-carboline, (11); Canthin-6-one, (12); Javacarboline, (13); Picrasidine G and (14); Picrasidine T.

occurring substances and their corresponding cationic derivatives were synthesized and evaluated for antiplasmodial activity. It was found that dehydrocrenatine (4-methoxy-1-vinyl- $\beta$-carboline) was effective against $P$. falciparum chloroquine sensitive strain (FCR-3) with the $\mathrm{EC}_{50}$ of $5.0 \times 10^{-6} \mathrm{M}$, while crenatine (1-ethyl-4-methoxy- $\beta$-carboline) showed as $E_{50}$ of $1.6 \times 10^{-5} \mathrm{M}$ (Takasu et al., 2004, 2005). Importantly, their salts; quaternary carbolinium cations not only showed much higher potencies than neutral $\beta$ carbolines, but also could increase selectivity between efficacy and toxicity. 
This research aimed to determine the $\beta$-carbolines, subclass of indole alkaloids, in Thai $P$. javanica by using thin layer chromatography (TLC) and high resolution mass spectrometry (MS).

\section{MATERIALS AND METHODS}

\section{Plant material}

The stem bark of $P$. javanica collected from Queen Sirikit Botanic Garden, Chiang Mai and was identified by comparison with the references deposited there (15 years).

\section{Preparation of crude extracts from $\boldsymbol{P}$. javanica stem bark}

The dried ground stem bark of $P$. javanica was macerated with hexane and dried in oven $\left(60^{\circ} \mathrm{C}\right)$. It was packed in plastic bag and kept at room temperature. In this study, about $100 \mathrm{~g}$ of dried ground hexane extracted $P$. javanica stem bark were successively extracted with chloroform and methanol. The fine ground and rough ground stem bark were macerated in $500 \mathrm{ml}$ chloroform and methanol for three days. Then, they were filtered and evaporated to dryness under reduced pressure. The residue plant materials were extracted again using the same process. The second extracts were pooled together with the first corresponding extracts.

\section{TLC system}

TLC aluminum sheet coated with silica gel GF 254 (Merck) was used as stationary phase. Mobile phase were chloroform-methanolwater (7:3:1), ethyl acetate (1:0), ethyl acetate-ethanol (8:2), ethyl acetate-ethanol (8:1), ethyl acetate-ethanol (8:2), ethyl acetateethanol (9.5:0.5), ethyl acetate-ethanol (9.9:0.1). Alkaloids were identified by UV light $(254 \mathrm{~nm})$ and color spot test with major alkaloidal test solutions; Wagner's reagent and Erdman's reagent (Soonthornchareonnon et al., 2008). 1-Ethyl- $\beta$-carboline (Junwised et al., 2019), 1-ethyl-1,2,3,4-tetrahydro- $\beta$-carboline (Saiin et al., 2018) and tiliacorinine (Saiin and Markmee, 2003) were used as standard alkaloids.

\section{High resolution mass spectrometry}

The high resolution mass spectrometry (MS) were taken with Agilent technologies; 6540 UHD Accurate mass QTOF LC/MS. Sample solution $(10 \mu \mathrm{g} / \mathrm{ml}$ methanol, $1 \mu \mathrm{l})$ was taken directly to MS and used positive charge electro spray ionization mode (+ESI).

\section{RESULTS AND DISCUSSION}

\section{Successively extraction of $\boldsymbol{P}$. javanica stem bark}

In order to wash the $\beta$-sitosterol and others lipophilic components, the stem bark was extracted with hexane. Then, the hexane extracted stem bark was extracted with chloroform. Finally, the chloroform extracted stem bark was extracted with methanol. The solution of methanol extract was taken directly to mass spectrometry.

It was found that the fine ground stem bark gave higher yield than rough ground stem bark both successively extraction with chloroform and methanol as showed in Table 1. It could be resulted from $\beta$-sitosterol; major compound in hexane extract (Saiin et al., 2003). Fine ground resulted in broken the cell and increase the area of the stem bark, thus $\beta$-sitosterol and others lipophilic components could be dissolved well.

\section{TLC chromatogram}

Various solvent systems were used as mobile phase for isolation of alkaloids in extracts. It was found that chloroform-methanol-water (7:3:1) and ethyl acetateethanol [(1:0), (8:2), (9:1), (9.5:0.5) and (9.9:0.1)] provided good separation. Wagner's reagent gave reddish-brown when reacted with the alkaloids in extracts and standards; 1-ethyl- $\beta$-carboline, 1-ethyl-1,2,3,4tetrahydro- $\beta$-carboline and tiliacorinine. Erdmann's reagent gave deep reddish-brown when reacted with alkaloids in extracts, 1-ethyl- $\beta$-carboline, 1-ethyl-1,2,3,4tetrahydro- $\beta$-carboline, but gave green color when reacted with tiliacorinine. Retardation factor (Rf) was calculated as showed in Table 2. 1-Ethyl- $\beta$-carboline was one of fourteen indole alkaloids isolated from $P$. javanica. Synthesized 1-ethyl- $\beta$-carboline and its derivative 1-ethyl$1,2,3,4$-tetrahydro- $\beta$-carboline were used to estimate the $\mathrm{Rf}$ value of other alkaloids in the extracts. Tiliacorinine was used to confirm that the reagents were reacted with alkaloids and molecular weight and polarity of tiliacorinine should similar with picrastidine $G$ and picrasidine $T$.

According to TLC chromatogram, the number of alkaloids found in the fine ground extracts were lower than the number of alkaloids found in the rough ground extracts as shown in Table 2.It might result from the interference effect of the lipophilic component in the fine ground extracts. In addition, chloroform extract gave smaller amount of alkaloids than methanol extract. These results corresponded to the report of Otmoto et al. (1987) who successively extracted the air dried bark of $P$. javanica growing in Indonesia with $n$-hexane, chloroform, and then methanol. The chloroform extract gave very low yield of crystal1-ethyl- $\beta$-carboline, crenatine, picrasidine I, crenatidine, and canthin-6-one. While the methanol extract gave higher yield of picrasidine I, picrasidine $\mathrm{J}$, and crude picrasidine $\mathrm{T}$.

\section{High resolution mass spectrum}

The methanol extract of rough ground was analyzed by using high resolution mass spectrometry as shown in Figure 2. The peak at $m / z 197.1074[\mathrm{M}+\mathrm{H}]^{+}$could be 1ethyl- $\beta$-carboline. The peak at $m / z 225.1035[\mathrm{M}+\mathrm{H}]^{+}$could 
Table 1. Crude extracts obtained from $P$. javanica stem bark.

\begin{tabular}{lcc}
\hline Crude extracts & Weights & \% yield \\
\hline Chloroform crude extract of fine ground stem bark (KC1) & 4.3892 & 4.39 \\
Methanol crude extract of fine ground stem bark (KM1) & 3.2528 & 3.48 \\
Chloroform crude extract of rough ground stem bark (KC2) & 1.7563 & 1.76 \\
Methanol crude extract of rough ground stem bark (KM2) & 1.9099 & 1.99 \\
\hline
\end{tabular}

Table 2. Rf value of alkaloids found in the extract of $P$. javanica stem bark.

\begin{tabular}{|c|c|c|c|c|c|c|c|c|c|}
\hline \multirow{2}{*}{ Mobile phase } & \multirow{2}{*}{ Detection } & \multicolumn{7}{|c|}{ Rf value } & \multirow{2}{*}{ Number of alkaloid } \\
\hline & & KC1 & KC2 & KM1 & KM2 & Std1 & Std2 & Std3 & \\
\hline \multirow{3}{*}{ Chroloform : methanol : water $(7: 3: 1)$} & \multirow{2}{*}{ Ultraviolet-Visible } & 0.27 & 0.27 & 0.29 & 0.29 & \multirow{2}{*}{0.89} & \multirow{2}{*}{0.27} & \multirow{2}{*}{0.27} & \multirow[t]{2}{*}{4} \\
\hline & & 0.91 & 0.91 & 0.91 & 0.81 & & & & \\
\hline & \multirow[t]{2}{*}{ Wagner's reagent } & - & - & - & - & 0.89 & 0.27 & 0.27 & - \\
\hline \multirow{6}{*}{ Ethyl acetate $(1: 0)$} & & 0.03 & 0.03 & 0.03 & 0.03 & \multirow{4}{*}{0.5} & \multirow{4}{*}{0.03} & \multirow{4}{*}{0.86} & \multirow{4}{*}{4} \\
\hline & \multirow{3}{*}{ Ultraviolet-Visible } & 0.60 & 0.60 & 0.60 & 0.60 & & & & \\
\hline & & 0.76 & 0.76 & 0.76 & 0.76 & & & & \\
\hline & & 0.92 & 0.92 & 0.92 & 0.92 & & & & \\
\hline & \multirow{2}{*}{ Wagner's reagent } & 0.03 & 0.03 & 0.03 & 0.03 & \multirow{2}{*}{0.5} & \multirow{2}{*}{0.03} & \multirow{2}{*}{0.86} & \multirow[b]{2}{*}{2} \\
\hline & & 0.92 & 0.92 & 0.92 & 0.92 & & & & \\
\hline \multirow{12}{*}{ Ethyl acetate : Ethanol (8:2) } & \multirow{4}{*}{ Ultraviolet-Visible } & 0.10 & 0.10 & 0.14 & 0.14 & \multirow{4}{*}{0.88} & \multirow{4}{*}{0.14} & \multirow{4}{*}{0.92} & \multirow{4}{*}{5} \\
\hline & & 0.89 & 0.89 & 0.89 & 0.30 & & & & \\
\hline & & 0.92 & 0.92 & 0.92 & 0.89 & & & & \\
\hline & & & & & 0.92 & & & & \\
\hline & & 0.10 & 0.10 & 0.14 & 0.14 & & & & \\
\hline & Whanor's rosant & 0.89 & 0.89 & 0.89 & 0.30 & 088 & 011 & 090 & 5 \\
\hline & vagnier s reagent & 0.92 & 0.92 & 0.92 & 0.89 & 0.00 & 0.14 & 0.92 & 3 \\
\hline & & & & & 0.92 & & & & \\
\hline & & 0.10 & 0.10 & 0.14 & 0.14 & & & & \\
\hline & Frdman's r & 0.89 & 0.89 & 0.89 & 0.30 & 088 & 014 & 0.92 & 5 \\
\hline & Eraman s reagent & 0.92 & 0.92 & 0.92 & 0.89 & 0.88 & 0.14 & 0.92 & 5 \\
\hline & & & & & 0.92 & & & & \\
\hline & & 0.03 & 0.03 & 0.03 & 0.03 & & & & \\
\hline & & 0.06 & 0.06 & 0.82 & 0.06 & & & & \\
\hline & Ultraviolet-Visible & 0.82 & 0.82 & 0.91 & 0.23 & 0.76 & 0.11 & 0.93 & 5 \\
\hline & & 0.91 & 0.91 & & 0.82 & & & & \\
\hline & & & & & 0.91 & & & & \\
\hline Ethyl acetate : Ethanol $(9: 1)$ & & 0.03 & 0.03 & 0.03 & 0.03 & & & & \\
\hline & & 0.06 & 0.06 & & 0.06 & & & & \\
\hline & Wagner's reagent & 0.82 & 0.82 & & 0.82 & 0.76 & 0.11 & 0.93 & 5 \\
\hline & & 0.91 & 0.91 & & & & & & \\
\hline & Erdman's reagent & - & - & - & 0.03 & - & 0.11 & - & - \\
\hline
\end{tabular}


Table 2. Continues.

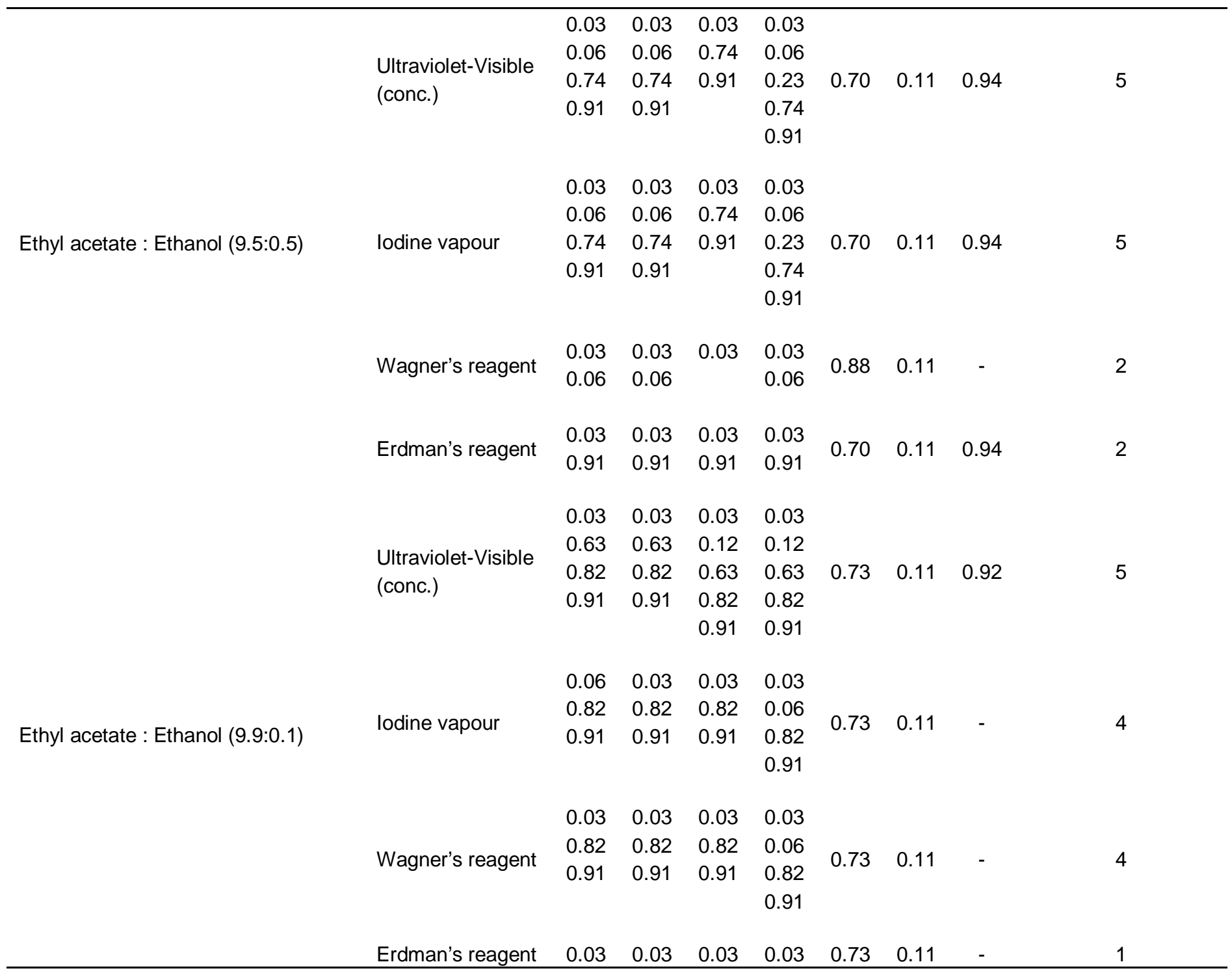

$\mathrm{KC} 1$ = Chloroform crude extract of fine ground stem bark, $\mathrm{KM} 1=$ Methanol crude extract of fine ground stem bark, $\mathrm{KC2}=\mathrm{Chloroform}$ crude extract of rough ground stem bark, KM2= Methanol crude extract of rough ground stem bark, Std1=1-ethyl- $\beta$-carboline, Std2= Tiliacorinine, Std3= 1-ethyl-1,2,3,4-tetrahydro- $\beta$-carboline.

be crenatine. The peak at $\mathrm{m} / \mathrm{z} 227.1184[\mathrm{M}+\mathrm{H}]^{+}$could be dehydrocrenatine. The peak at $\mathrm{m} / \mathrm{z} 241.0981[\mathrm{M}+\mathrm{H}]^{+}$ could be 5 - or 6- or 8- hydroxydehydrocrenatine. The peak at $\mathrm{m} / \mathrm{z} 243.1134[\mathrm{M}+\mathrm{H}]^{+}$could be $5-$ or 8hydroxycrenatine. The peak at $\mathrm{m} / \mathrm{z} 449.1986[\mathrm{M}+\mathrm{H}]^{+}$ could be picrasidine $\mathrm{G}$. The peak at $\mathrm{m} / \mathrm{z} 481.1886\left[\mathrm{M}^{+}\right.$ could be picrasidine $T$. According to reviewing the structure of indole alkaloids isolated from $P$. javanica by Saiin and Sirithunyalug (2017), it was found two suspects. First, 6-hydroxydehydrocrenatine (6-hydroxy-4methoxy-1-vinyl- $\beta$-carboline) reported by Pavanand et al. (1988) may be 5-hydroxydehydrocrenatine as reported by
Arbain and Sargent (1987). Second, picrastidine T hydrochloride $(\mathrm{m} / \mathrm{z} 448$ [M-HCl]) reported by Ohmoto et al. (1987) must be picrastidine $G$ hydrochloride. In addition, the present findings reported the peak at $\mathrm{m} / \mathrm{z}$ 481.1886 that should be picrastidine $\mathrm{T}$.

\section{Comparison the $\beta$-carbolines found in Thai and Indonesian $P$. javanica}

According to the TLC data, high resolution MS data and literature review data, it is shown that Thai $P$. javanica 

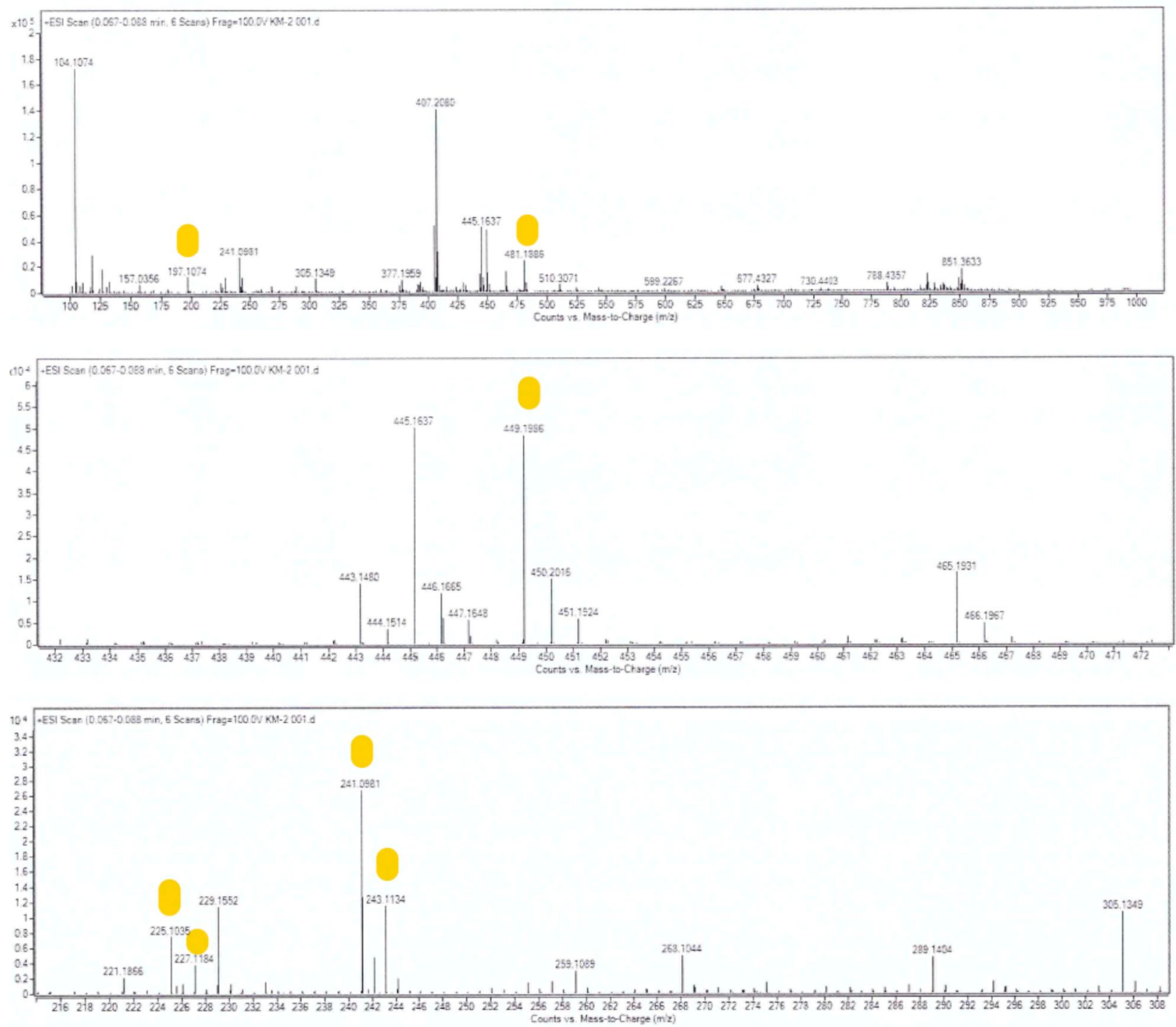

Figure 2. High resolution mass spectra (+ESI) of methanol extract showed the $m / z[M+H]^{+}$at 197.1074, 225.1035, 227.1184, 241.0981, 243.1134, 449.1986, and 481.1886.

composed of the $\beta$-carbolines as same as Indonesian $P$. javanica, shown in Table 3 . These compounds are potentially important for development of antimalarial drugs.

Table 3. Comparison of the $\beta$-carbolines found in Thai and Indonesian $P$. javanica.

\begin{tabular}{llll}
\hline \multirow{2}{*}{ Solvent used } & Single extracted & Successively extracted & \\
\cline { 2 - 4 } & Thai $\boldsymbol{P}$. javanica & Indonesian $\boldsymbol{P}$. javanica & Thai $\boldsymbol{P}$. javanica \\
\hline \multirow{4}{*}{ Chloroform } & Dehydrocrenatine, & 1-ethyl- $\beta$-carboline, & Identified by TLC: \\
& 6-hydroxydehydrocrenatine & crenatine, & (1) 1-ethyl- $\beta$-carboline, \\
& (Pavanand et al., 1988) & picrasidine I, & (2) Crenatine and/or Dehydrocrenatine, \\
& crenatine, & crenatidine, & (3) 5- or 6- or 8-dehydrocrenatine or 5- \\
& dehydrocrenatine & canthin-6-one & and/or 8-hydroxycrenatine, \\
& (Saiin et al., 2016) & (Ohmoto et al., 1987) & (4) picrasidine T and/or picrasidine G \\
\hline
\end{tabular}


Table 3. Continues.

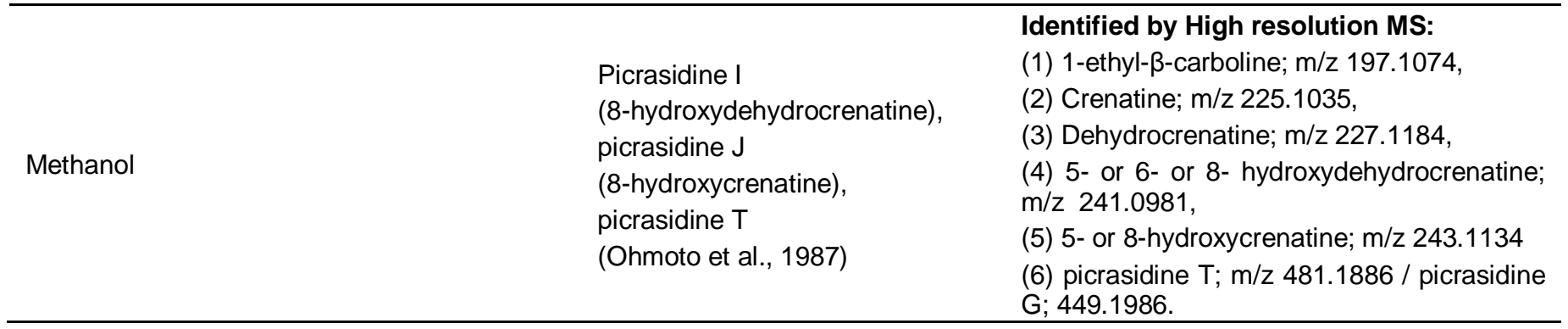

\section{CONCLUSION}

It could be concluded that $P$. javanica grown in Thailand composed of the $\beta$-carbolines similar to that grown in Indonesia. In addition, these results supported the use of $P$. javanica as medicinal plant for treatment of malaria. All fourteen $\beta$-carbolines of $P$. javanica should be synthesized and studied their antimalarial activity and toxicity.

\section{ACKNOWLEDGEMENT}

This research was financial supported by Faculty of Pharmaceutical Sciences, Naresuan University.

\section{REFERENCES}

Arbain D, Sargent MV, 1987. The alkaloids of Picrasma javanica. Aust J Chem, 9: 1527-1536.

Johns SR, Lamberton JA, Sioumis AA, 1970. 4-Methoxy-1-vinyl- $\beta$ carboline, a new alkaloid from Picrasma javanica (Simaroubaceae). Aust J Chem, 23: 629-630.

Junwised J, Saiin C, Takasu K, Ihara M, 2019. Synthesis, cytotoxicity and in vitro antimalarial activity of 1 -ethyl- $\beta$-carbolinine; an indole alkaloid of Picrasma javanica Bl., Proceeding of the $57^{\text {th }}$ Kasetsart University Annual Conference; Glocalization to Digitized Thailand. Bangkok: Kasetsart University, 35-42.

Ketusinh O, 1948. Report on Clinical Antimalarial Therapy of Thai Medicinal Plants. Proceeding of the Siriraj $60^{\text {th }}$ Aniversary Meeting, 275-281.

Koike K, Ohmoto T, Uchida A, Onishi I, 1994. Javacarboline, A new $\beta$ carboline alkaloid from the stem of Picrasma javanica in Java. Heterocycles, 38(6): 1413-1420.

Ohmoto T, Koike K, Mitssunaga K, 1987. Alkaloids from Picrasma javanica growing in Indonesia. Shoyakugaku Zasshi, 41(4): 338-340.

Old Style Doctor Association, 1962. Pra-muan-sappa-kun-yathai.Part I. Bangkok: Am-phon-pittaya, p107.

Pavanand K, Yongvanitchit K, Webster HK, Dechatiwongse T, Nutakul $\mathrm{W}$, Jewvachdamrongkul $\mathrm{Y}$, Bansiddhi J, 1988. In vitro antimalarial activity of a Thai medicinal plant Picrasma javanica Bl. Phytother Res, 2: 33-36.

Saiin C, Markmee S, 2003. Isolation of antimalarial active compound from Yanang (Tiliacora triandra Diels). The Kasetsart J Nat Sci, 37(1): 47-51.

Saiin C, Rattanajak R, Kamchonwongpaisan S, Ingkaninan K, Sukontason K, Baramee A, Sirithunyalug B, 2003. Isolation and in vitro antimalarial activity of hexane extract from Thai Picrasma javanicaBI. stem bark. Southeast Asian J Trop Med Public Health, 34(Supp 2): 51-55.

Saiin C, Sirithunyalug B, 2017. Review of the chemical structures and antimalarial activities of indole alkaloids isolated from Picrasma javanica BI. stem bark. Adv Med Plant Res, 5(2):29-36.

Saiin C, Sirithunyalug B, Baramee B, TakasuK, Ihara M, 2018. The Convenient method for synthesis of crenatine; an antimalarial agent of Picrasma spp.Proceeding of the $56^{\text {th }}$ Kasetsart University Annual Conference; Agriculture science toward creative economy. Bangkok: Kasetsart Universsity, 152-159.

Saiin C, Sirithunyalug B, Rattanajak R, Kamchonwongpaisan S, Baramee A, Sukontason K, Ingkaninan K, 2016. In vitro antimalarial activity of Thai Picrasma javanicaBI. stem extract. Asian J Nat Appl Sci, 5(4): 8-13.

Saiin C, Sirithunyalug B, Rattanajak R, Kamchonwongpaisan $S$, Ingkaninan K, Baramee A, Sukontason K, 2016. Isolation and in vitro antimalarial activity of chloroform extract from Thai Picrasma javanicaBl. stem bark. Adv Med Plant Res, 4(3): 94-98.

Soonthornchareonnon N, Sotanaphun U, Wongsinkongman P, 2008. TLC: A simple method for qualitative analysis of Thai crude drugs. Nonthaburi: Department for Development of Thai Traditional and alternative Medicine, 466p.

Takasu K, Shimogama T, Saiin C, Kim HS, Wataya Y, Ihara M, 2004. $\pi$-Delocalized $\beta$-carbolinium cations as potential antimalarials. Bioorg Med Chem Lett, 14: 1689-1692.

Takasu K, Shimogama T,Saiin C,Kim HS,Wataya Y, BrunR, Ihara M, 2005. Synthesis and evaluation of $\beta$-carbolinium cations as new antimalarial agents based on pi-delocalized lipophilic cation (DLC) hypothesis. Chem Pharm Bull (Tokyo), 53(6): 653-661.

Tangjitman K, Wongsawad C, Winijchaiyanan P, Sukkho T, Kamwong $\mathrm{K}$, Pongamornkul $\mathrm{W}$, Trisonthi $\mathrm{C}$, 2013. Traditional knowledge on medicinal plant of the Karen in northern Thailand: a comparative study. J Ethnopharmacol, 150(1): 232-243.

Yoshikawa M, Harada E, Aoki S, Yamahara J, Murakami N, Shibuya H, Kitagawa I, 1993. Indonesia medicinal plants. VI. On the chemical constituents of the bark of Picrasma javanica BI. (Simaroubaceae) from Flores island. Absolute stereostructures of picrajavanins $A$ and B. Chem Pharm Bull, 41(12): 2101-2105.

Citation: Saiin C, Junwised J, Nuengchamnong N, Ingkaninan K, 2019. Determination of $\beta$-carbolines in Thai Picrasma javanica Bl.; the source of potential antimalarial agents. Adv Med Plant Res, 7(2): 61-67. 